https://doi.org/10.3126/pragya.v7i1.35109

\title{
INTERNATIONAL MigRATION LEVEL AND TRENDS
}

Kunwar Laxman Singh, PhD

\begin{abstract}
:
International migration is an issue growing concern at global, regional and national level because its volume has been increasing at all level. Among the four migration corridors (North-North, North-South, South-North and South-South) of international migration South-South migration (developing countries -developing countries) occupies largest and North- South (developing countries -developed Countries) second largest share of international migration. The objective of this study is to introduce the situation of international migration at global, regional and national level by using secondary sources of information. The volume of refugees in relation with volume of international migration also has been increasing. Similarly the volume of emigrants have increased in those countries or regions with having very low, low and middle level human development index. Whereas the volume of more immigrants was observed in countries or regions of high and very high human development index. In the context of Nepal, international migration (absentee population data in censuses) has been gradually increasing but up to 2001 censuses major destination was India but on the basis of 2011 census destination of Nepalese migrants have been shifted to Middle East and ASEAN countries but India still remains as a major destination. The lack of uniform data regarding to international migration has been a problem to analyze migration level and trends properly.
\end{abstract}

Key Words: International Migration, Remittances, Human development and Migration Corridor.

\section{Background:}

International migration occurs when people cross state boundaries and stay in the host state for some minimum length of time. Labour migration is defined as the movement of persons from their home State to another State for the purpose of employment. The International Labour Organization (ILO) defines a migrant worker as an "international migrant individual of working age and older who are either employed or unemployed in their current country of residence". This term is a subset of international migrant. The ILO (2018) estimated that 6 of every 10 international migrants were migrant workers in 2017 . Only 4 of every 10 migrant workers were women. Around 68 per cent of migrant workers resided in high income countries. The current global estimate is that there were around 272 million international migrants in the world in 2019, which equates to 3.5 per cent of the global population (IOM, 2020). 
Today, an estimated 86 million persons are working in a country other than their country of birth. Despite the efforts made to ensure the protection of migrant workers, many migrants continue to experience numerous problems particularly more vulnerable groups, such as female domestic workers, entertainers and lower skilled workers. In countries of origin labour migration can relieve pressure on unemployment and can contribute to development through the channeling of remittances, transfer of know-how, and the creation of business and trade networks. In countries of destination facing labour shortages, orderly and well-managed labour migration can lighten labour scarcity, facilitate mobility, and add to the human capital stock (IOM, 2018).

\section{Objectives:}

The objective of this paper is to introduce the situation of international migration at national, regional and global level. This article also has aim to highlight the major determinants international migration.

\section{Data and Method:}

The article is based on secondary sources of information about international migration. Relevant data sources from International Organization for Migration (IOM), International LabourOrganization (ILO), United Nations Department of Economic and Social Affairs (UN DESA), Global Commission on International Migration (GCIM), United Nations Development Programs (UNDP) and other national and regional published literature related to the objectives of this paper have been used.

\section{Result and Discussion:}

The result and discussion of this article are being discussed at three scenario which are at global, regional and national level.

\section{Global Scenario:}

Each year millions of women and men leave their homes and cross national borders in search of greater security for themselves and their families. "Throughout human history, migration has been a courageous expression of the individual's will to overcome adversity and to live a better life" (UN, 2006). Many migrants are motivated by the quest for higher wages and better opportunities, responding to the demand for their skills abroad, but many others are forced to migrate because of famine, natural disasters, violent conflict, persecution or simply a lack of decent work in their home country. The Global Commission on International Migration (GCIM) describes the driving forces in international migration in terms of "3Ds": development, demography and democracy 
(GCIM, 2005). The United Nations Population Division (UNPD) estimates that the world's stock of migrants, defined as persons residing outside their country of birth or citizenship. The stock of international migrants has increased in the world population from 2.3 per cent in 1975 to 3.1 per cent in 2010 (UNPD, 2009). Currently in 2019, 3.5 per cent of world population (IOM, 2020). Out of the total number, 60 per cent were estimated to live in developed regions (IOM, 2020).

As compared to the 2000 Global Migration Report, the number of international migrants has nearly doubled in the 2020 report, from 150 million to 272 million. India is followed by Mexico (11.8 million) and China (10.7 million). Roughly two-thirds of international migrants are labour migrants. India accounts for the highest share with 17.5 million Indians are living outside the country and leading recipient of remittances; out of $\$ 689$ billion India received $\$ 78.6$ billion, which is consistently increased between 2005 and 2020. The top migration corridors for Indians are United Arab Emirates, The US and Saudi Arabia. Roughly, two-thirds of international migrants are labour migrants. The United States has been top remittance-issuer at $\$ 68$ billion, followed by the United Arab Emirates ( $\$ 44.4$ billion) and Saudi Arabia (\$36.1 billion). Similarly, top destination country in 2019 for international migrants is the US and followed by Germany, Saudi Arabia, Russian Federation and the UK. The share of female and children international migration is 47.9 per cent and 13.9 per cent respectively (Insights IAS, 2020).

Refugees are also a form of international migration and which has been also in increasing trends.

Fig 1: International migrants and registered refugees, as a percentage of world population, 1960-2017 


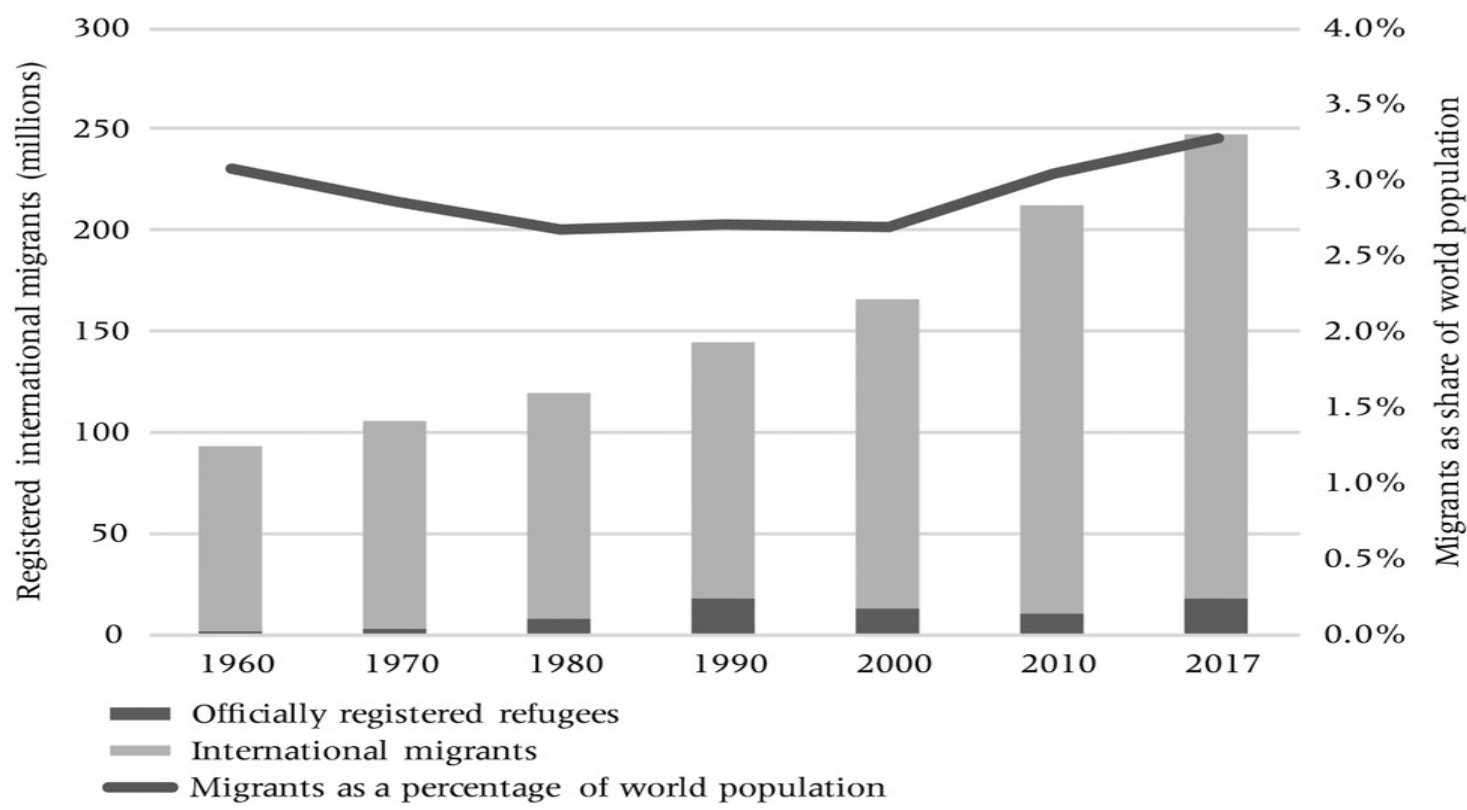

Source: De Hass et al, 2019

From the above fig (1) both volume of international migrants and refugees have been gradually increased. In 2017, international migrants share nearly 3.5 per cent of world population among international migrants refugees shared slightly less than 0.5 per cent.

Migration has major impacts on both the people and the places involved in it. When supported by appropriate policies, migration can contribute to inclusive and sustainable development in both origin and destination countries, while also benefitting migrants and their families.

Population Division examines the latest migration levels and trends by geographic, development and income grouping, based on the 2019 revision of the International Migrant Stock, which found that the number of international migrants globally reached an estimated 272 million in 2019. That represents an increase of 51 million since 2010 (UN DESA, 2019). Currently, international migrants comprise 3.5 per cent of the global population, compared to 2.8 per cent in the year 2000.In 2019, regionally, Europe hosts the largest number of international migrants ( 82 million), followed by Northern America (59 million) and Northern Africa and Western Asia (49 million) (IOM, 2020).

At the country level, about half of all international migrants reside in just 10 countries, with the United States of America hosting the largest number (51 million), equal to about 19 per cent of the world's total. Germany and Saudi Arabia host the second and third largest numbers of migrants (13 million each), followed by the Russian Federation (12 million), the United Kingdom (10 million), the United Arab Emirates (9 million), France, Canada and Australia (around 8 million each) and Italy (6 million). Concerning their place of birth, one-third of all international migrants originate from only ten countries, with India 
as the lead country of origin, accounting for about 18 million persons living abroad. Migrants from Mexico constituted the second largest "diaspora" (12 million), followed by China (11 million), the Russian Federation (10 million) and the Syrian Arab Republic (8 million) (UN DESA, 2019).

\section{Regional Scenario:}

International migration from poor, developing countries ("the South") to rich, developed countries ("the North") represents little more than a third of the global total. South-South migration between developing countries represents almost the same proportion, and NorthNorth migration between developed countries represents a little less than a third(UNPD, 2009). Most South-North migration is headed for Europe and the United States, while North-North migration mainly takes place within Europe and across the Atlantic. As noted, however, considerable migration for employment is also taking place between developing countries. According to World Bank estimate, about half of all migrants from developing countries reside in other developing countries, and almost 80 per cent of South-South migration takes place between contiguous countries (Ratha and Shaw, 2007). Many countries are both sources of and destinations for migrants. Canada, for example, is a traditional destination for migrants, but Canada also sends significant numbers of people, particularly the highly skilled, to the United States. Similar phenomena have emerged in Asia. For example, Thailand receives many low-skilled immigrants from Cambodia, the Lao People's Democratic Republic and Myanmar, and also sends its own workers to other countries, including Israel, the Republic of Korea and Taiwan (China).

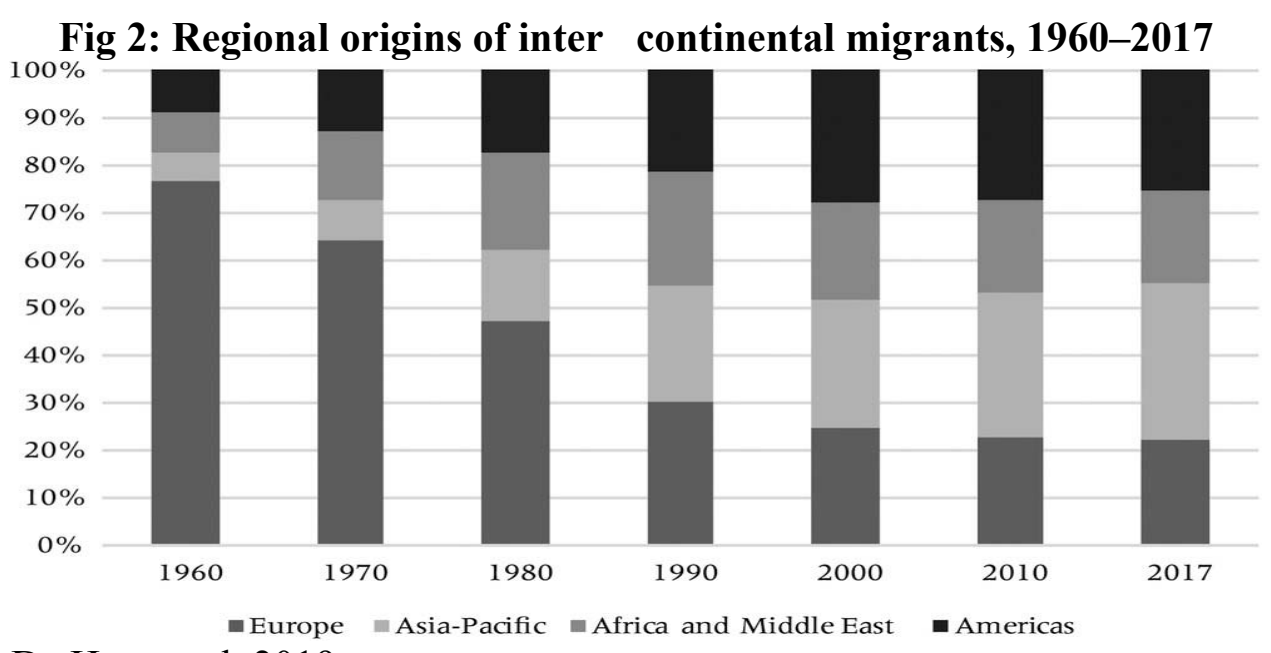

Source: De Hass et al, 2019

From the above fig (2) Europeans made up 76 percent of all long distance migrants in 1960, this percentage decreased to 22 percent in 2017, coinciding with increasing long distance migration from other world regions, particularly in the Asia Pacific region. In 1960, an estimated 8 percent of emigrants from Asia had moved outside the region; in 2017 this share had soared to 58 percent. When countries achieve higher development 
levels emigration decrease alongside increasing immigration, leading to their transformation from net emigration to net immigration countries.

\section{Fig 3: levels of development and migration}

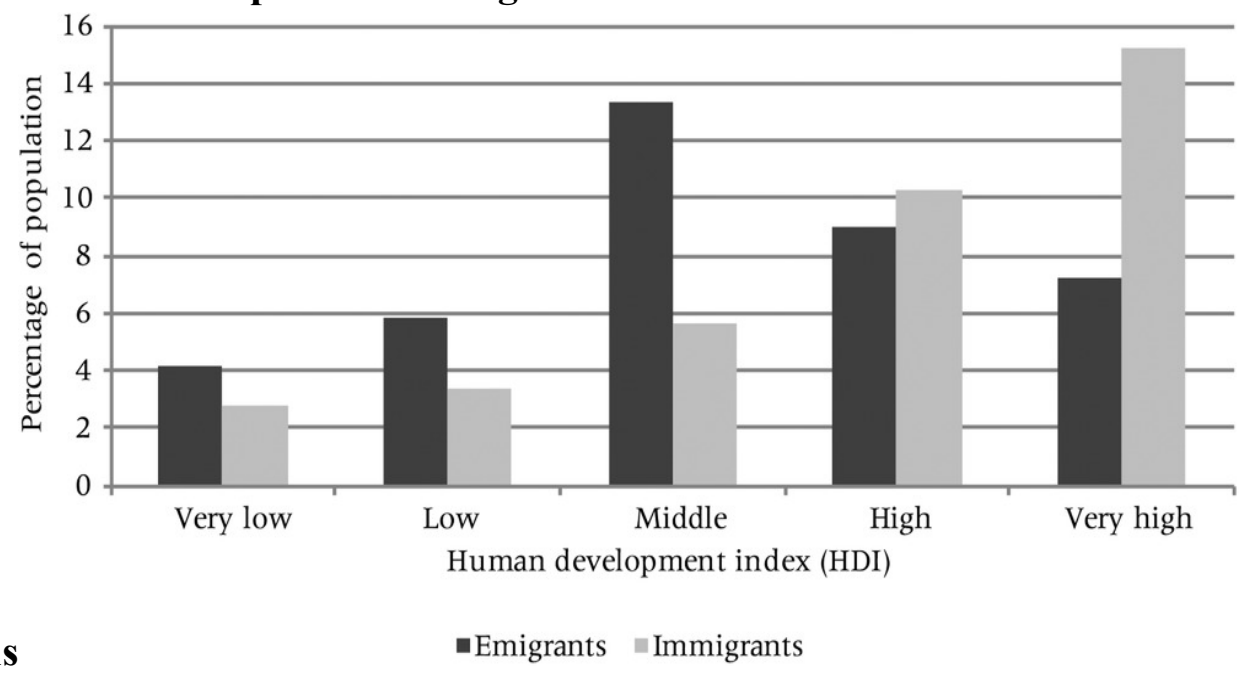

patterns

Source: De Hass et al, 2019

The above fig (3) reflects that the volume of emigrants have increased up to with those countries of middle level of human development index. Similarly in those countries with high and very high level of human development index the volume of immigrants are high. It helps to conclude that the volume and direction of emigrants and immigrants are determined by human development index of a particular country.

Fig 4: Region wise Share of Volume of International Migrants by Region of Residence, 2015

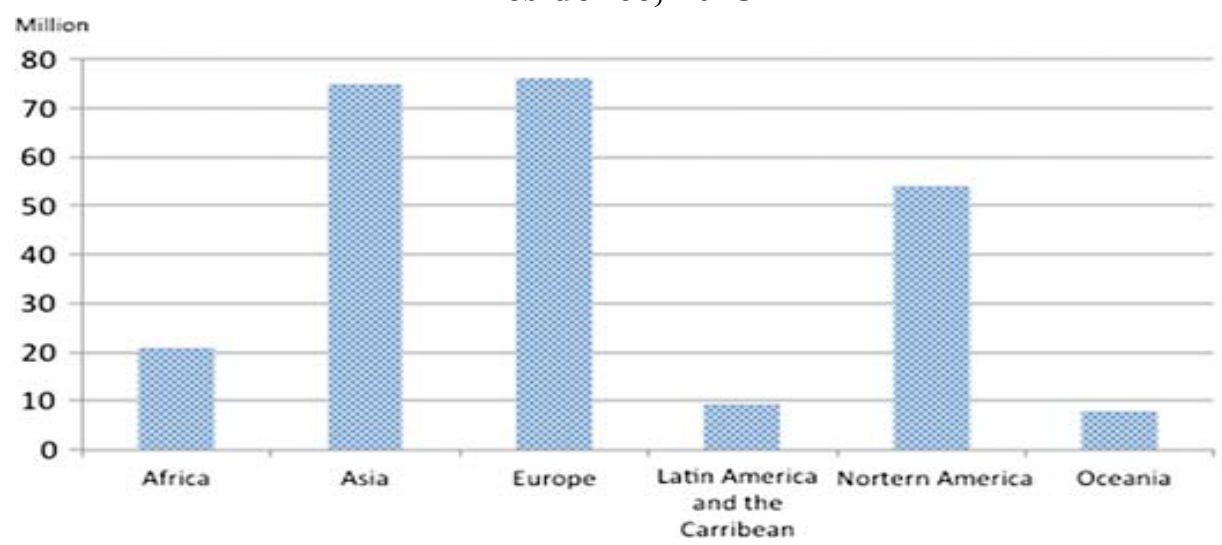

Source: UN DESA, 2015.

From above fig (4) the major share of international migrants' residence was observed in Europe, Asia and North America respectively. Africa holds fourth position, Latin America and Oceania fifth and sixth positions on the basis of residence of international migrants in 
2015.

Europe-to-Europe constituted the largest regional migration corridor in the world, with 41.9 million international migrants born in Europe and residing in another country in the same region, of which a considerable proportion were between countries of the European Union. From 2000 to 2010 and from 2010 to 2019, the Europe-to-Europe regional migration corridor increased by more than 5 million international migrants, an average annual increase of more than half a million. The corridor from Latin America and the Caribbean to Northern America was the second largest migration corridor in 2019, with a stock of 26.6 million international migrants. While this regional migration corridor grew by 0.9 million migrants per annum between 1990 and 2000, the growth decelerated in the more recent period. Between 2000 and 2010 and between 2010 and 2019, the number of international migrants in this corridor increased by an average of 0.5 and 0.3 million per year, respectively. The third, fourth, and fifth largest regional migration corridors were almost equal in size in 2019, with around 18 to 19 million international migrants for each of these corridors. The number of international migrants within Northern Africa and Western Asia increased by 7.3 million between 2010 and 2019, while the corridor from Central and Southern Asia to Northern Africa and Western Asia grew by 5.4 million. The number of sub-Saharan African migrants residing in sub-Saharan Africa changed only slightly between 1990 and 2010 but then increased by 5.4 million between 2010 and 2019 (IOM, 2020).

\section{National Scenario:}

Nepal's migration situation is dominated by migration of Nepalese for foreign employment. The 2011 census on population and housing showed that almost 50 per cent of Nepal's households had a member who was either working overseas or had returned. While this labour migration has a significant positive effect on Nepal's economy, it also has a series of socioeconomic impacts on the welfare of Nepali nationals and their communities. Exploitation of migrant workers is rife and aspiring labour migrants may find themselves in a situation of irregular migration or trafficking. Nepal's environmental vulnerability also has an impact on the scale of internal and international migration. Climate change, environmental degradation, natural and man-made disasters causes displacement and dislocation from the land, meaning that many Nepalese migrate to ensure a sustainable livelihood.

Nepal's open border with its close neighbor India is another defining and unique characteristic in Nepal's migration context. Although the lack of data on this issue is of concern, it is recognized that there are frequent and extensive cross-border movements, which have significant impacts for Nepal, both positive and potentially negative. The 2011 census data shows that nearly twofifths $(37.2 \%)$ of the Nepali absentees are in India, however such data has its limitations in the case of an open border where crossing can be short-term or seasonable and will be undocumented. There are also no records kept on how many Nepalese work in India or where they are. Traditionally, Nepali migrant workers sought employment mainly in India, however from the mid-1980s, Nepalese started also to 
migrate to the Gulf States and Malaysia for work which resulted in an increase in migrant workers as well as in a proliferation of labour recruitment agencies and brokers. The decentralization of passport issuance in Nepal also facilitated the migration of many unskilled and semi-skilled Nepalese (IOM, 2019).

Table 1: Absentee Population in Nepal (1911-2011)

\begin{tabular}{|l|l|l|l|l|l|l|l|}
\hline Year & Total Population & Absentee & $\%$ & Male & $\%$ & Female & $\%$ \\
\hline 1911 & $56,38,794$ & - & - & - & - & - & - \\
\hline 1920 & $55,73,788$ & - & - & - & - & - & - \\
\hline 1930 & $55,32,574$ & - & - & - & - & - & - \\
\hline 1942 & 6283640 & 87722 & 1.4 & - & - & - & - \\
\hline $1952 / 54$ & 8256625 & 198120 & 2.3 & 173619 & 87.6 & 24501 & 12.4 \\
\hline 1961 & 9412995 & 328470 & 3.2 & - & - & - & - \\
\hline 1971 & 11555983 & - & - & - & - & - & - \\
\hline 1981 & 15022839 & 402977 & 2.6 & 328448 & 81.5 & 74529 & 18.5 \\
\hline 1991 & 18491097 & 658290 & 3.4 & 548002 & 83.2 & 118288 & 16.8 \\
\hline 2001 & 23151423 & 762181 & 3.2 & 679489 & 89.2 & 82712 & 10.8 \\
\hline 2011 & 26494504 & 1921494 & 7.3 & 1684029 & 87.6 & 237400 & 12.4 \\
\hline
\end{tabular}

Source: Central Bureau of Statistics 2014

\section{Destinations of Nepalese International Migrants:}

A majority of international migrants continue to go to India, possibly a reflection of geographic proximity, cultural ties, and the open border with India. Following India, most migrant workers are destined either for countries in the Middle East or ASEAN member states (primarily, Malaysia). During the Fiscal Year 2013/14, approximately 44.2 per cent of the total labour permits issued were to migrants going to the Gulf countries and 39.6 per cent to those going to Malaysia (MOLE, 2015).

Table 2: Destinations of Nepalese Emigrants, 2019

\begin{tabular}{|l|l|l|}
\hline SN & Destination countries & Share of $\%$ \\
\hline 1 & India & 37.60 \\
\hline 2 & Middle East & 37.60 \\
\hline 3 & ASEAN Countries & 13.0 \\
\hline 4 & European Countries & 3.30 \\
\hline 5 & Other Asian Countries & 2.90 \\
\hline 6 & USA and Canada & 2.50 \\
\hline 7 & Other Countries & 2.10 \\
\hline 8 & Not Stated & 1.10 \\
\hline
\end{tabular}

Source: IOM, 2019.

Historically, Nepal has seen reasonable rates of international migration, albeit mostly to India. Between 1961 and 2001, the migrant to population ratio hovered around 3.4 percent, and was almost entirely driven by migration to India (Table 1). This rate was slightly 
higher than the global international migration rate of 2.9 percent (UNDESA, 2015). The high rate can be attributed to the ethno-linguistic similarity between the two countries as well as the low cost of migration to India. Nepal maintains an open border with India, where citizens from one country are free to enter the other at any time without any restrictions, paperwork or clearances. This allows workers of either country to take advantage of the economic opportunities in the other. Historically, workers, mostly from Far-western and Mid-western regions of Nepal, have been migrating to India to work as daily wage laborers or security guards or in restaurants in Indian cities. Because of frequent migration to India over a long period, there are well-established migration linkages between districts in Nepal and Indian cities that help newer migrants find work in India (Seddon, Adhikari, and Gurung, 2002). Because of the open border and historical linkages, India serves as the low cost and low return destination for Nepali migrants.

\section{Conclusion:}

The volume of international migration has been increased globally. There is no uniform pattern region wise migration in the world. South-South migration is larger than SouthNorth migration. Over 38 percent of the international migrants in 2013 migrated from developing countries to other developing countries, compared to 34 percent that moved from developing countries to advanced countries. The top 10 migrant destination countries were the United States, Saudi Arabia, Germany, Russia, United Arab Emirates (UAE), United Kingdom, France, Canada, Spain and Australia. The top 10 migrant source countries were India, Mexico, Russia, China, Bangladesh, Pakistan, the Philippines, Afghanistan, Ukraine, and United Kingdom. In the context of Nepal, the volume of absentee population has been increasing and the major destination of absentee population was India up to 2001 census and still it persist but after 2001 the diversification of absentee population has been gradually shifting to Middle east and ASEAN countries. Reliable data on migrants and migration are crucial for assessing current and future trends, identifying policy priorities, and making informed decisions. Reliable data on migration can help ensure that discussions on migration, at global, regional and national levels based on facts but due to variation of available data from different sources it has been difficult to analyze properly.

\section{References:}

Central Bureau of Statistics (2014). Population Monograph of Nepal Vol. I (Kathmandu: Central Bureau of Statistics).

De Hass Hein, Czaika Mathias, FlahauxMarire-Laurence, Mahendra, Edo, Natter Katharina, VezzoliSimonaVillares-Varela Maria (2019). International Migration: Trends, Determinants and Policy Effects. Retrieved from https:// doi.org/10.1111/padr.12291.

Global Commission on International Migration (2005). Summary of the Report of the Global 
Commission on International Migration (New York: Population Division Department of Economic and Social Affairs, United Nations Secretariat).

International LabourOrganization (2018). Global Estimates on International Migrants workers,

Result and Methodology (second edition reference year 2017) (Geneva: International labour Organization).

International Organization for Migration (2018). World Migration Report, 2018 (Geneva: International Migration for Migration).

International Organization for Migration (2019). Migration in Nepal: A Country Profile (Kathmandu: International Organization for Migration).

International Organization for Migration (2020). Word Migration Report 2020 (Geneva: International Organization for Migration).

International Organization for Migration (2020). World Migration Report, 2020 (Geneva: International Migration for Migration).

Ministry of Labour for Employment (2015). Labour Migration for Employment: A status Report for Nepal 2014/15 (Kathmandu: Ministry for Labour and Employment).

Ratha, D., \& W. Shaw. 2007. —South-South Migration and Remittances.l World Bank

Ratha, Dilipand Shaw, William (2007). South-South Migration and Remittances, Working Paper, No 102 (Washington D. C. The World Bank).

Seddon, Adhikari, and Gurung, 2002) Adhikari, J., Gurung, G., Seddon, D. (2002). Foreign labor migration and the remittance economy of Nepal: Critical Asian Studies. Vol. 34, 2002ssue I, Retrieved from https://doi.org/10.1080/146727102760166581.

United Nations (2006). International Migration Report: 2006 A Global Assessment (New York: United Nations).

United Nations Department of Economic and Social Affairs(2015). International Migration Report, 2015 (New York: United Nations, Department of Economic and Social Affairs).

United Nations Department of Economic and Social Affairs (2015). International Migration Report, 2015 (New York: United Nations, Department of Economic and Social Affairs).

United Nations Department of Economic and Social Affairs (2019). International Migration Report, 2019 (New York: United Nations, Department of Economic and Social Affairs).

United Nations Development Project (2009). Human Development Report, Over Coming Barriers: Human Mobility and Development (New York: United Nations Development Programme). 